This item was submitted to Loughborough's Research Repository by the author.

Items in Figshare are protected by copyright, with all rights reserved, unless otherwise indicated.

\title{
STEPS: a knowledge management maturity roadmap for corporate sustainability
}

\section{PLEASE CITE THE PUBLISHED VERSION}

\section{PUBLISHER}

(C) Emerald Group Publishing Limited

\section{VERSION}

AM (Accepted Manuscript)

\section{LICENCE}

CC BY-NC-ND 4.0

\section{REPOSITORY RECORD}

Robinson, Herbert S., Chimay J. Anumba, Patricia M. Carrillo, and Ahmed M. Al-Ghassani. 2019. "STEPS: A Knowledge Management Maturity Roadmap for Corporate Sustainability”. figshare.

https://hdl.handle.net/2134/4189. 
This item was submitted to Loughborough's Institutional Repository (https://dspace.lboro.ac.uk/) by the author and is made available under the following Creative Commons Licence conditions.

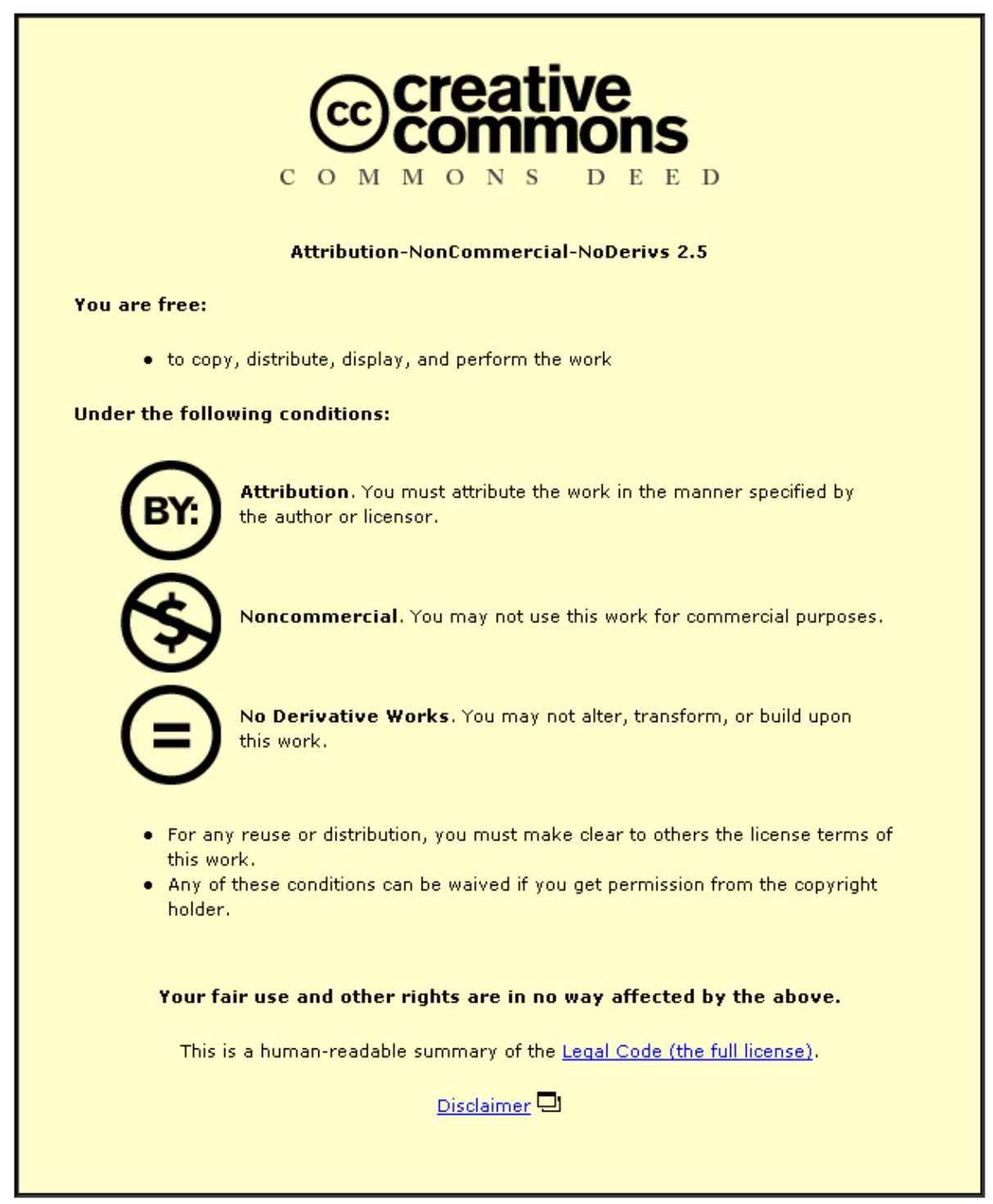

For the full text of this licence, please go to: http://creativecommons.org/licenses/by-nc-nd/2.5/ 


\title{
STEPS: A Knowledge Management Maturity Roadmap for Corporate Sustainability
}

\author{
H.S. Robinson, C.J Anumba, P.M Carrillo and A. M Al-Ghassani \\ Department of Civil and Building Engineering \\ Loughborough University \\ Loughborough \\ Leicestershire LE 11 3TU, UK
}

Dr Herbert Robinson is a Senior Lecturer at London South Bank University. His industrial experience includes working on major construction projects at Arup (UK) and World Bank funded Projects in The Gambia. His current research interests focus on knowledge management, business performance improvement and privately financed infrastructure projects.

Professor Chimay Anumba holds the chair in Construction Informatics and he is the founding Director of the Centre for Innovative Construction Engineering at Loughborough University. His industrial experience spans over 14 years. He has recently held Visiting Professorships at the Massachusetts Institute of Technology (MIT) and Stanford University.

Dr Patricia Carrillo is a Senior Lecturer in Construction Management in the Department of Civil and Building at Loughborough University, UK and Visiting Professor at the University of Calgary, Canada and University of Colorado at Boulder, USA. She has worked in industry and her research interests focus on knowledge management, business performance, mergers and acquisitions, and strategic management.

Dr Ahmed Al-Ghassani is the Assistant Dean in Salalah College of Technology in Oman. Prior to that, he was the Head of the Construction Department and has also served for several years in the private and public sectors. His research interests include improving the process of structural design, knowledge management, and IT use in Construction.

\section{Author for Correspondence}

Dr Patricia Carrillo

Department of Civil and Building Engineering,

Loughborough University,

Loughborough, Leicestershire LE 11 3TU, UK

E-Mail: P.M.Carrillo@lboro.ac.uk

Phone: +44 (0) 1509222634

Fax: $\quad+44(0) 1509223945$ 


\begin{abstract}
Research paper

Purpose

The paper focuses on the role of knowledge management in promoting corporate in the construction industry context. It proposes a maturity roadmap - STEPS to facilitate the implementation of a knowledge management strategy.
\end{abstract}

\title{
Design/methodology/approach
}

Two research methods were used. The first consisted of a postal questionnaire sent to the top 170 UK construction firms consisting of engineering design and construction contractor firms. The organisations were selected because they were considered the most influential organisations in the UK construction sector. The second research method involved 28 case study interviews with eight construction firms to investigate their approach to knowledge management and performance improvement. The results of the questionnaire survey and the case studies were used to develop the STEPS Maturity Roadmap.

\section{Findings}

The paper found that knowledge management is inextricably linked to corporate sustainability, but a methodical approach is required for successful knowledge management implementation. With this is mind, the STEPS Maturity Roadmap was developed to provide a structured approach to implementing and benchmarking knowledge management efforts.

\section{Practical implications}

This will allow companies to understand were they fall within the STEPS Maturity Roadmap and to devise a strategy to be developed to attain higher levels of knowledge management maturity.

\section{Originality/value}

This paper provides a mechanism for organisations to benchmark their knowledge management activities and to develop a knowledge management strategy that would improve their activities.

Key words: construction organisations, corporate sustainability, knowledge assets, knowledge management 


\section{INTRODUCTION}

Following the UN World Summit for Sustainable Development at Johannesburg in 2002, the global consequence of the commercial activities of organisations has been subjected increasingly to the 'sustainability' microscope. Corporate sustainability has become a major policy issue in recent years following some high profile business failures in an attempt to promote good governance (Aaronson, 2002). These developments provided the catalyst for a change in business logic requiring organisations to simultaneously address issues relating to finance, human development, environmental quality and social equity. However, unlike financial issues, environmental and social issues are often perceived to be less tangible and difficult to measure. Investors, customers and society are gradually increasing the level of commitment and support for organisations embracing the concept of corporate sustainability (Knoepfel, 2001). Such an approach signals a gradual shift from the shareholder to stakeholder economy, and an increased emphasis on nonfinancial measures (intangible assets). This trend is likely to gain momentum given recent initiatives such as the Global Reporting Initiative (GRI) for promoting sustainability reports by capturing non-financial information, the Dow Jones Sustainability Group Index for ranking organisations according to corporate sustainability performance, and the UK corporate sustainability awards. There are also other significant developments such as the SIGMA Guidelines (2003) aimed at embedding sustainability principles within core business processes. The guidelines are supplemented by the Environmental Accounting and Sustainability Accounting toolkits to enable organisations to translate sustainability principles into practice. 
A survey of the top 100 companies shows that the construction and building materials sector is one of the worst with $9 \%$ producing separate non-financial reports, significantly lower than the average of 23\% (KPMG International, 2003). The figures for other sectors are $50 \%$ for utilities, oil and gas (38\%), pharmaceuticals (30\%) electronics and computers (25\%) and retail (15\%). The construction industry has been identified as one of the most unsustainable industrial sectors and there is increasing awareness of the need for improvement through initiatives such as the Construction Best Practice Programme (CBPP), and Movement for Innovation (M4I). The most recent industry review recognised the need for sustainability of construction processes through innovation (Fairclough, 2002). Sustainability of construction processes, products and services creates stakeholder value, and is crucial for the long-term viability of construction firms. The principles of sustainability as it applies to construction, and the benefits have been discussed by Chen and Chambers (1999), Ofori (1998), Bossink (2002), and Wenblad (2001).

Knowledge management is central to the sustainability debate, and its importance is reflected through the role of human and social capital in the SIGMA Guidelines (2003) for putting sustainability development into practice. Knowledge management promotes continuous improvement, facilitates innovation in business processes and products, embraces people as architects at the centre of the knowledge creation process, and enhances stakeholder relationship management. Stewart (1997) argues that an 'organisation's capacity to innovate depends considerably on the knowledge of its staff, knowledge embodied in business processes and customer relationships'. A survey by KPMG (1998) revealed that $43 \%$ of organisations had knowledge management initiatives, and one in ten considered it to be transforming the way they 
do business. Within the context of construction organisations, the role of knowledge management as a source of competitive advantage have been addressed. See for example, Kululanga et al (2001), Egbu (1999) and Carrillo et al (2000). Patel et al (2000) argued that knowledge management and organisational learning are recognised by the larger construction firms as potentially important but little has been attempted at a formal level. The difficulty for many organisations is that the implementation of knowledge management has often been ad hoc without a roadmap to follow.

This paper focuses on the role of knowledge management in promoting corporate sustainability and presents a maturity roadmap to facilitate the implementation of a knowledge management strategy. Following the introduction, the research objectives and methodology is outlined in the next section. The relationship between corporate sustainability and knowledge management principles are explored and key findings from a survey and case studies on knowledge management practices in construction organisations are presented. The concept and application of the STEPS (Start-up, Take-off, Expand, Progress, and Sustain) maturity roadmap, underpinned by the survey and case studies, is discussed. The paper concludes that the roadmap will ensure that knowledge management is not only implemented in a structured way but will enable organisations to assess their readiness and to benchmark their knowledge management implementation efforts to achieve the goals of corporate sustainability.

\section{RESEARCH OBJECTIVES AND METHODOLOGY}

This study is part of a major research project sponsored by the EPSRC and industrial collaborators investigating the relationship between knowledge management and business performance in construction organisations. The aim of the project is to 
develop a performance-based framework to facilitate the implementation of knowledge management in construction organisations.

Discussions with industrial partners and a literature review provided the basis for identifying key issues and a number of structured questions for an industry survey. Questionnaires were posted to the top 100 firms appearing in the UK's New Civil Engineer Contractors File and the top 70 firms from the Engineering Consultants File. These organisations were surveyed because they are considered the most influential groups in the UK construction sector. Out of a total of 170 questionnaires sent out, 53 completed questionnaires were received, giving a response rate of $31.2 \%$. This is considered to be good for a mail or postal questionnaire mainly due to the follow-up telephone contacts after the questionnaires were sent.

Case study interviews were then conducted with eight organisations supporting the research project as industrial collaborators. These are large construction contractors consisting of a balanced mix of four national and four international firms. A total of 28 interviews were carried out with senior managers lasting from half an hour to two hours. Between 2 to 5 people were interviewed in each organisation to capture different perspectives on a range of issues relating to knowledge management and performance improvement. The findings from the survey and case study investigations provided the basis for developing the knowledge management maturity roadmap (STEPS). 


\section{CORPORATE SUSTAINABILITY AND KNOWLEDGE MANAGEMENT}

Adopting sustainability principles requires proactive management of financial, human, environmental and social capital and a shift from the shareholder to the stakeholder perspective. Corporate responsibility is at the centre of the sustainability debate, to improve governance by managing both hard physical (tangible) and soft knowledge (intangible) assets. Sustainability principles should therefore be related to the context of the business i.e. it should address issues of what is produced (products projects/services), how it is produced (processes), by whom (people) and its implication for stakeholders - investors, consumers and society. In the context of construction, this means, for example, a need to be involved in environmentally, socially acceptable and ethically sound projects, using processes that enhances regulatory compliance, minimises waste, rework, defects and pollution, and delivered by people trained in sustainability and working within a safe environment. Figure 1 shows some of the issues relating to the sustainability agenda for a construction organisation that goes beyond the creation of economic wealth to include environmental and social considerations.

\section{Take in Figure 1: Sustainability Agenda for Construction Organisations}

Sustainability should be addressed not only for environmental concerns or society's expectations but because it makes good business sense. For example, improvements in construction processes and safety practices reduce accident-related costs, and the significant costs associated with wastage, defects and rework. Up to $30 \%$ of construction is rework and a high proportion of materials are wasted (Egan, 1998). Reduction in waste and pollution could result in significant savings in landfill 
charges, fuel-related costs for the disposal of waste, as well as sanctions and fines for breaching environmental regulations.

Sustainability is not only about damage limitation but improving understanding, and the responsiveness to investors, employees and consumer needs in order to develop 'an enhanced reputation that leads to greater staff, customer and investor loyalty' (WWF, 2003). The benefits from better corporate governance includes improved access to capital, improved human development and labour practices by reducing the risks often associated with dirty and dangerous construction sites. The net effects are significant cost savings, revenue gains from an improved public profile and image, loyalty, brand value, improved market access and a significant increase in repeat businesses.

\section{Knowledge Assets as 'Roots' of Corporate Sustainability}

The change in business logic means that there is now a shift from focussing on shortterm harvesting of the fruits of success (profitability and increasing shareholder value) to nurturing the roots (building knowledge assets and stakeholder value) for long-term trust, improved governance and sustainability. The value creation concept showing the relationship between hard physical (tangible) and soft knowledge (intangible) assets of an organisation is illustrated in Figure 2 using Skandia's tree metaphor.

\section{Take in Figure 2: Skandia's Tree Metaphor}

Like the roots of a tree - the knowledge or intangible assets are the invisible parts of organisations, which have to be nurtured to harvest the fruits - i.e. improve the value of financial assets, and access to financial capital through debt and equity investors. 
Intangible assets are made up of intellectual capital and property such as technology competence, patents, trademarks, and goodwill. Intellectual capital is defined as the economic value associated with structural (organisational), customer and human factors in organisations. The structural factor (capital) refers to organisational processes, software, hardware, and supply chains that remains after employees go home. Human capital is what remains in employees heads when they go home such as their know-how and creativity. Customer capital is associated with products and knowledge about customer relationships with consumers, society and other stakeholders. The SIGMA Guidelines (2003) explicitly incorporates the dimensions of human and social capital, alongside, other types of capital crucial in achieving the goals of sustainability. Bringing knowledge or intangible assets to the forefront of an organisation's business strategy, will therefore, have a significant impact on the future wealth of organisations. This is because knowledge represents a significant proportion of the market value of some organisations and there is now an increasing realization of the importance of managing intangible assets. Skandia, a large Swedish insurance and financial services company, was the first organisation to introduce an intellectual capital report to persuade investors of the value of an organisation's knowledge (Edvinnson, 1997).

However, information on knowledge assets considered to be a major source for creating wealth and value, and the driver for innovation is often not available. But the situation is gradually changing due to a number of reasons:

- Existing accounting/ measurement frameworks focusing on hard tangible (financial) assets are no longer considered to reflect an organisation's value. Soft 
intangible assets of knowledge, such as R \& D, and intellectual assets now form a significant component of the value of modern knowledge organisations. There are a number of tools developed to track the value of knowledge assets such as the Skandia Navigator (Edvinsson, 1997), the Intangible Assets Monitor (Sveiby, 1997), the Balanced Scorecard by Kaplan and Norton (1996), the Excellence Model (EFQM, 1999) and more recently the SIGMA Guidelines (2003) and associated toolkits.

- The shift in focus from reactive quality inspection to proactive Total Quality Management. Sommerville and Robertson (2000) argued that 'an organisation adopting the principles of Total Quality Management quickly appreciates that financial measures on their own are very limited in reflecting the wider aspects of achievements and progress in general'.

- The growth in non-financial reporting following recent initiatives such as the Global Reporting Initiative. Thomas Stewart, editor of the influential Harvard Business Review, in his book entitled 'Intellectual Capital - The New Wealth of Organisations' argued that 'it would be a mistake to mingle measures of intellectual capital with financial data, it would be a greater one not to use them at all'.

- Growing interest from stakeholders for more informed corporate reporting to address transparency and to build public trust following recent high profile business failures. Samuel DiPiazza Jr, Chief Executive Officer of PriceWaterhouseCoopers, and Robert Eccles, former professor at Harvard 
Business School, in their book entitled 'Building Public Trust: The Future of Corporate Reporting' argued that organisations should provide a broader range of information than financial reporting regulations require (DiPiazza and Eccles, 2002).

The economic importance of knowledge (intangible or non-financial assets) has long been recognised. However, incorporating information relating to knowledge assets to accurately reflect an organisation's value is a growing concern for investors, governments, regulatory bodies such as the accountancy profession and other stakeholders (European Commission, 2003). There is a need to manage knowledge assets relating to people (human capital), embedded in business processes (structural capital), customer relationship or products (customer capital).

\section{Knowledge Implications for Sustainability}

If knowledge or intangible assets are the roots of organisations, then knowledge management is about nurturing or strengthening those roots. Knowledge management is defined as 'any process of creating, acquiring, capturing, sharing and using knowledge, wherever it resides, to enhance learning and performance in organisations' (Scarborough et al, 1999). Developing a knowledge management strategy therefore enables an organisation to unlock and leverage the different types of knowledge, to identify competencies required to become a forward thinking and learning organisation with the ability to put sustainability principles into practice.

There is a need for the development of appropriate measures reflecting sustainability objectives and to assess their knowledge implications for continuous improvement. 
For example, designing out waste is a major issue for many construction firms. However, using 'number of skips' as a measure of wastage may inform the finance/accounting department about the level of waste in monetary terms but such information is of limited use to the environmental department. This is because it is important to understand the nature of waste - i.e. composition by type of materials, void space, causes of waste, etc - in order to develop a knowledge strategy for waste reduction. A knowledge management strategy is therefore vital if corporate sustainability objectives are to be achieved.

\section{KNOWLEDGE MANAGEMENT PRACTICES}

As knowledge management is central to achieving the goals of corporate sustainability, it is important for organisations to have the capacity to develop and implement a KM strategy. O'Leary (2001) argued that knowledge management systems could help attract and nurture top talent, as 'maximising access to knowledge across the organisation' can accelerate the learning experience of new employees, build more knowledge (human capital) to increase organisational capability. It can also drive innovation, help to attract new or retain valuable customers (customer capital), improve responsiveness to the needs of society (social capital) and in the process, attract investors and increase profitability (financial capital) to enhance stakeholder value. The following section examines the KM experience of construction organisations based on the survey and case studies.

\section{Survey}

The survey was undertaken to examine the drivers of knowledge management; investigate the reform and resources required; and to identify performance 
measurement practices in construction organisations. A summary of the key findings is presented below.

\section{$\underline{\text { Motivation and Awareness }}$}

- The main reasons or motivation for knowledge management are:

(1) to share tacit knowledge of key employees;

(2) disseminate best practices; and

(3) to reduce rework.

- Over three-quarters (77\%) of organisations are aware of the benefits of knowledge management. About $86 \%$ of larger organisations compared to $36 \%$ of smaller organisations (employing less than 500).

\section{$\underline{\text { KM Strategy and Implementation }}$}

- About $42 \%$ have a strategy and $32 \%$ are planning a strategy in the short-term. Half of the larger organisations compared to a fifth of smaller organisations have a strategy.

- $45.3 \%$ have appointed a Knowledge Manager or a team to implement their KM strategy.

- About three-quarters (74\%) identified the Intranet as the main tool used to support their strategy. 
- One third of the organisations use Communities of Practice (CoPs) or related Technical Networks. (43\% of large organisations compared to $7 \%$ of small organisations).

\section{$\underline{\text { Performance Measures }}$}

Over $85 \%$ of the organisations use a combination of financial and non-financial measures to assess business performance. Financial measures such as profit, turnover and sales are still dominant. However, a growing number of organisations are now using non-financial measures.

- About 90\% measure customer characteristics.

- $64 \%$ have measures for employees such as job satisfaction, working conditions and opportunities for learning and growth.

- About $62 \%$ of have measures for product performance.

- Just under half (47\%) have measures for processes.

- Two-thirds (66\%) use measures to assess impact on society such as pollution, safety, accidents and resource preservation.

However, there are some differences in measurement practices between the design activities carried out by consultants, and the construction activities of contractors. The end product of construction is a building or structure, tangible and highly visible. In contrast, the end product of design is often perceived to be less tangible and visible. Measures on society are considered more important from a contractor's perspective as construction activities have direct effects on the lives of communities during and after 
construction. The increased awareness in measuring the impact on society is in response not only to the need to minimise the environmental effects of construction activities but as part of the corporate sustainability agenda to give something positive back to society (i.e. to build social capital).

\section{Performance Measurement Models}

Following the Egan (1998) report on "Rethinking Construction" in the UK, significant interest has been generated in measurement using Key Performance Indicators (KPIs). Awareness of the use of the Balanced Scorecard (Kaplan and Norton, 1996) and the Excellence Model (EFQM, 1999) has also increased.

- $\quad$ Over three-quarters (77\%) have a business performance measurement system.

- About $15 \%$ are using more than one measurement system.

- A third (34\%) of the organisations use KPIs.

- Under a quarter (23\%) use the Excellence Model on its own compared to $13 \%$ for the Balanced Scorecard.

\section{$\underline{\text { Knowledge Management Maturity }}$}

In terms of knowledge management implementation, almost two-thirds (63\%) considered their approach to be 'ad hoc' characterised by a high degree of fragmentation and lack of co-ordination. 23\% of organisations have a 'managed' approach (i.e. structured and co-ordinated). The remaining 14\% consider their approach as somewhere between 'ad hoc' and 'managed'. The results show that there is a need for improved implementation of KM but significant barriers identified such as 
the lack of standard work processes, time and organisational culture need to be addressed.

\section{Case Study Findings}

The case studies provided an in-depth analysis of issues critical to the implementation of knowledge management. A summary of the key findings are given below:

\section{$\underline{\text { Motivation and Awareness }}$}

The primary goal for knowledge management varies from seeking best practices to providing a better service to clients. However, the overall objective was to improve business performance and profitability. Although organisations are aware of the importance and the benefits of KM there are differences in perception. Some see KM as synonymous with managing information where the role of Knowledge Manager is wrongly perceived as a technical librarian for managing information on the Intranet. There is clearly a difference between knowledge and information. As Malhortra (2000) explained 'this strategic difference is not a matter of semantics; rather, it has critical implications for managing and surviving in an economy of information overabundance and information overload'.

\section{$\underline{\text { KM Strategy }}$}

Three out of eight organisations have a KM strategy and the rest are fine-tuning or planning a strategy in the short term. Central to their KM strategy are the talents of people as tacit knowledge is more valuable for engendering innovation. However, none of the organisations have a coherent structure and the absence of a working definition also reflects the casual approach to KM. 


\section{$\underline{\text { KM Resources }}$}

Some organisations enjoy a higher degree of top management support than others do. Three have established full-time leadership positions - one chief knowledge officer and two knowledge managers - supported by budget, IT infrastructure, and support staff on a full-time or part-time basis. Whilst it is true that the role is more important than the title, support on an ad hoc basis can be a source of distraction, as it increases the vulnerability to pressures from other conflicting activities.

\section{$\underline{\text { KM Tools }}$}

The Intranet is the backbone of the KM infrastructure but several organisations have started to develop Extranets to facilitate collaboration with other firms on specific projects. However, there is widespread evidence that most organisational knowledge is in people's heads and processes, and IT is not capable of capturing tacit knowledge without losing its context. There is recognition that more effort should be directed to setting up non-IT systems such as communities of practice to facilitate person-toperson and person-to-organisation interactions.

\section{$\underline{\text { Reward schemes }}$}

None of the organisations have reward schemes for knowledge sharing. However, two organisations, currently without a KM strategy, are exploring reward systems as part of their performance appraisal system. Financial reward systems are difficult to operationalise compared to non-financial systems such as peer acclaim. It is usually better to delay the introduction of incentive schemes until KM practices are mature. 


\section{$\underline{\text { Barriers }}$}

The main barrier identified is organisational culture considered as one of the most crucial factors and 'perhaps the most difficult constraint that knowledge managers must deal with' (Davenport et al 1997). KM is not only a technical problem involving the use of IT but a socio-cultural one involving motivating people. One organisation has a change management programme to inculcate a positive attitude to knowledge sharing and recognition. Another key barrier is demonstrating the benefits of KM. Others include fear, attitudes or resistance to knowledge sharing, initiative overload, poor IT infrastructure, lack of top management support, and conflicting priorities between KM and other business functions.

\section{Links between KM and business improvement}

Most organisations recognise the need for $\mathrm{KM}$ but there are difficulties in demonstrating its benefits, as it is not explicitly linked to business strategy. Several organisations have identified demonstration projects as KM initiatives but methods are not put in place to monitor and communicate the benefits. Publicising the results can help maintain KM as a high profile activity and increase the level of awareness.

\section{KNOWLEDGE MANAGEMENT MATURITY ROADMAP}

The survey and case studies show that: (1) KM and performance measurement is becoming important in the construction context; and (2) there is a need for a structured approach to facilitate and benchmark implementation efforts. Key success factors identified includes the following:

- Need to establish a goal, develop and align KM strategy to business objectives.

- Provide leadership and resources including management support, staff and budget. 
- Implementation needs to be supported by both IT and non-IT tools.

- Recognition of reform needed to address barriers and to facilitate implementation.

- KM performance measures required to evaluate KM.

The questionnaire survey and case study findings provided the basis for the development of the maturity roadmap discussed in the next section.

\section{Five Steps to Sustainability}

A maturity roadmap could help organisations to structure and implement knowledge management and to benchmark their implementation efforts. The concept of the maturity roadmap is illustrated below (see Figure 3).

\section{Take in Figure 3: Concept of KM maturity}

The vertical scale reflect the key attributes of knowledge management from low to high level activities. Low level activities such as understanding the concept of knowledge management and awareness of the benefits relate to attributes at the startup stage. High level activities are associated with the advanced stage such as measurement, incentivisation and diffusion. These attributes reflect current themes in KM such as the need to identify the reform required, the resource implications and the need for a result monitoring system to review the impact of KM. The horizontal scale reflects 'attribute dimensions' from low to high performance. For example, the dimensions for the attribute 'resources' could vary from limited to sufficient, and for 'goals' from vague to refined. The dimensions for attribute 'awareness of benefits' is from preaching to practice, and for 'diffusion' it is from localised to widespread. The 
five steps in the maturity roadmap, STEPS (Start-up, Take-off, Expand, Progress, and Sustain) reflect varying levels of KM maturity. Each level is characterised or associated with certain attributes and attribute dimensions. Key aspects of the roadmap is shown in Figure 4, reflecting different emphasis at various stages as detailed below:

\section{Take in Figure 4: The STEPS Maturity Roadmap}

\section{$\underline{\text { Stage 1: Start-up }}$}

Organisations at this stage are the least advanced and are characterised by:

- An understanding of the concept of KM, different perspectives and its practical implications;

- An appreciation of the benefits of KM, at least, in theory;

- Recognition of the potential of KM in building the value of knowledge assets for continuous improvement; and

- Establishing the need for KM and the willingness to share knowledge

\section{Stage 2: Take-off}

The take-off stage involves:

- Establishing the goals of KM;

- Exploring strategic options. This could be demand driven (delivered in real time where and when it is needed) or supply driven (available in a central repository). The focus could be on people interactions (personalisation) or documents or IT (codification or computerisation);

- Developing a KM strategy with a working definition to facilitate consensus; 
- Establishing leadership and identifying resources for consultancy and support;

- Identifying barriers and risks associated with the strategy and possible changes required; and

- Experimentation with KM on an ad hoc basis, localised or very small scale.

\section{Stage 3: Expansion}

The expansion stage is characterised by:

- Refining the KM strategy and linking KM to specific business objectives;

- Increasing the visibility of KM leadership, and the allocation of resources (budget, staff, IT infrastructure);

- Implementing change management programme to address barriers and risks identified;

- Implementing KM initiatives in a structured and co-ordinated way, and identifying appropriate KM tools to support specific initiatives;

- Increasing the scale of KM initiatives to other business units, projects and offices; and

- Introducing performance measures to evaluate KM and communicate the benefits of knowledge assets.

\section{$\underline{\text { Stage 4: Progressive }}$}

The progressive stage is characterised by:

- Integrating KM activities to strategic measurement frameworks such as the Balanced Scorecard and the Excellence Model to monitor and evaluate knowledge assets; 
- Establishing evaluation criteria and targets for measuring the impact on knowledge assets and justifying KM initiatives;

- Introducing reward and incentive schemes to strengthen KM activities; and

- Increased visibility and communication of the benefits from most KM activities.

\section{Stage 5: Sustainability}

At the sustainable stage, KM becomes institutionalised and is characterised by:

- $\quad \mathrm{KM}$ becoming linked to all business objectives;

- KM practices diffused in the entire organisation;

- KM becoming embedded in organisational culture, employees' behaviour, business processes and product development; and

- Widespread reporting on the performance of knowledge assets underpinning corporate sustainability.

\section{Application and Discussions}

The STEPS maturity road map was used to assess the maturity of eight case study organisations. Figure 5 shows the position of the case study organisations in the KM maturity scale. The black ovals indicate ratings based on the interviewees' perception of the current positions of their companies. The white ovals show the research team's objective assessment of the relative positions of the case study organisations following the studies.

\section{Take in Figure 5: KM Maturity Levels of case study organisations}

The researchers' ratings are based on an analysis of the key attributes of KM using the STEPS maturity roadmap. Within each stage ratings were used to indicate whether the characteristics are superficially, partially evident or fully evident. The assessment 
shows that four organisations have over-estimated their level of maturity, one has under-estimated it, while the remaining three have made a reasonably accurate estimate.

The case studies illustrate that construction organisations are at various levels of maturity in implementing KM. One organisation is at the expansion stage and has made reasonable good progress. Two are at the take-off stage and have made limited to modest progress, and the others are at the start-up stage. All four case study organisations (A, C, E and $\mathrm{H}$ ) leading in the maturity scale are international companies with significant presence in various parts of the world. The remaining four, (B, D, F and G), are all national, UK-based companies at the start-up stage, exploring KM, without a strategy, resources and a dedicated leadership. The findings confirm that there is a greater need for larger international organisations to implement KM systems as they tend to have a significant amount of knowledge that is more diverse and geographically dispersed to manage. The roadmap is intended to be used as a tool to identify weaknesses with respect to essential factors and to develop an action plan with appropriate measures to improve implementation i.e. the reform necessary, provide the resources to support KM and to evaluate the results of KM. Depending on the positions of organisations, action plans reflecting various gaps in reform, resources and results monitoring systems required, could be developed to improve the maturity of KM implementation and to achieve the goals of sustainability. Organisations are more likely to realise the full potential of KM if the necessary steps to maturity are translated to action plans. 


\section{CONCLUSION}

This paper has demonstrated that corporate sustainability is inextricably linked to knowledge management. Corporate sustainability has resulted in a fundamental shift in business logic requiring organisations to simultaneously address environmental and social issues, alongside traditional financial issues. Developing a knowledge management strategy is central to operationalising the concept of sustainability as improvement in the way knowledge assets are managed and reported can lead to better corporate governance, facilitate continuous improvement and enhance stakeholder value.

Failure to integrate sustainability principles into an organisation's business strategy could result in a loss of competitive advantage and business opportunities, which will undermine long-term performance. The STEPS maturity roadmap is a structured approach to determine the steps involved and the actions required to implement knowledge management, and to benchmark implementation efforts to achieve the goals of corporate sustainability. Construction organisations are expected not only to embrace the concept of sustainability but also to apply its principles as a way of doing business and managing its knowledge assets to facilitate continuous improvement in organisational performance. The initial focus of the work reported on the STEPS maturity roadmap is based on analysis from construction organisations, however, the framework could be applicable in other industrial sectors. 


\section{REFERENCES}

Bossink, B. A. G. (2002), “A Dutch Public Private Strategy for Innovation in Sustainable Construction, Construction Management and Economics”, Vol 20 No 7, pp. 633-642.

Carrillo, P.M, Anumba, C.J. and Kamara, J.M. (2000). Knowledge Management Strategy for Construction: Key IT and Contextual Issues, in Proceedings of CIT 2000, Reykjavik, Iceland, 28-30 June, Gudnason, G. (Ed.), pp. 155-165.

Chen, J.J and Chambers, D. (1999), “Sustainability and the Impact of Chinese Policy Initiatives upon Construction”, Construction Management and Economics, Vol 17 No 5, pp. $679-687$.

DiPiazza, S. A., (Jr) and Eccles, R. G. (2002), Building Public Trust: The Future of Corporate Reporting, John Wiley and Sons, New York.

Davenport, T.H., De Long, D.W. and Beers, M.C. (1997), "Building Successful Knowledge Management Projects". Centre for Business Innovation, Ernst \& Young, Working Paper, January.

Egan, J. (1998), Rethinking Construction: Report of the Construction Task Force on the Scope for Improving the Quality and Efficiency of the UK Construction Industry, Department of the Environment, Transport and the Regions, London

Edvinnson, L, (1997), “Developing Intellectual Capital at Skandia”, Long Range Planning, Vol. 30 No 3, pp. 366-373.

EFQM (1999), Eight Essentials of Excellence: The Fundamental Concepts and their Benefits, European Foundation for Quality Management, Brussels.

Egbu, C.O. (1999) "The Role of Knowledge Management and Innovation in Improving Construction Competiveness", Building Technology and Management Journal, Vol 25, pp1 - 10. 
European Commission (2003), Study on the Measurement of Intangible Assets and Associated Reporting Practices, Abridged version, Based on Final Report of EU Call for Tender ENTR/01/054, Contract n. FIF. 20010720, May

Fairclough, J. (2002) "Rethinking Construction Innovation and Research: A review of Government R \& D Policies and Practices”, Department for Transport and Local Government Regions (DTLR), London.

Kaplan, R.S. and Norton, D. P. (1996), “The Balanced Scorecard - Measures that Drive Performance”, Harvard Business Review, Vol 70 No 1, pp. 71-79.

Knoepfel, I (2001), “Dow Jones Sustainability Group Index: A Global Benchmark for Corporate Sustainability”, Corporate Environment Strategy, Vol. 8 No 1, pp. 6 15.

KPMG Management Consulting (1998), Knowledge Management Research Report, KPMG Management Consulting, London.

KPMG International (2003), Best Practice for the Retail Sector: Briefing on KPMG's Corporate Sustainability Reporting Survey 2002, KPMG Management Consulting, London.

Kululanga, G. K. and McCaffer, R. (2001). “Measuring knowledge management for construction organizations.” Engineering, Construction and Architectural Management, Vol 8 No 5/6, pp. 346-354

Malhotra, Y. (2000), “Knowledge Management for E-Business Performance: Advancing Information Strategy to "Internet Time"”, Information Strategy, The Executive's Journal, Vol. 16 No 4, , pp 5-16

Nonaka, I. and Takeuchi, H. (1995). The Knowledge-Creating Company: How Japanese Companies Create the Dynamics of Innovation, Oxford University Press, New York. 
Ofori, G. (1998), “Sustainable Construction: Principles and a Framework for Attainment”, Construction Management and Economics, Vol 16 No 2, pp. $141-145$

O'leary, D.E., (2001), “How Knowledge Reuse Informs Effective System Design and Implementation”, IEEE Intelligent Systems, Vol 16 No 1, pp. 44 - 49.

Patel, M. B., McCarthy, T.J., Morris, P.W.G and Elhag, T.M.S (2000), The Role of IT in Capturing and Managing Knowledge for Organisational Learning on Construction Projects, in Proceedings of CIT 2000, Reykjavik, Iceland, 28-30 June, Gudnason, G. (Ed.), pp. 674-685.

Sigma Guidelines (2003), Putting Sustainable Development into Practice: A Guide for Organisations. Available on http://www.projectsigma.com

Sommerville, J. and Robertson, H.W. (2000), “A Scorecard Approach to Benchmarking for Total Quality Construction”, International Journal of Quality and Reliability Management, Vol. 17 Nos. 4/5, pp. 453-466.

Stewart, T.A. (1997), Intellectual Capital: The New Wealth of Organisations, Doubleday Dell Publishing Group, New York

Sveiby, K.E (1997). The New Organizational Wealth: Managing \& Measuring Knowledge-Based Assets. Berrett-Koehler Publishers, San Francisco. WWF (2003), Building a Business Case for Sustainability. Available at http://www.wwf.org.uk/core/about/ta_0000000482.asp.

Wenblad, A. (2001), "Sustainability in the Construction Business - A Case Study”, Corporate Environment Strategy, Vol. 8 No 2, pp. 157-164. 
Figure 1: Sustainability Agenda for Construction Organisations

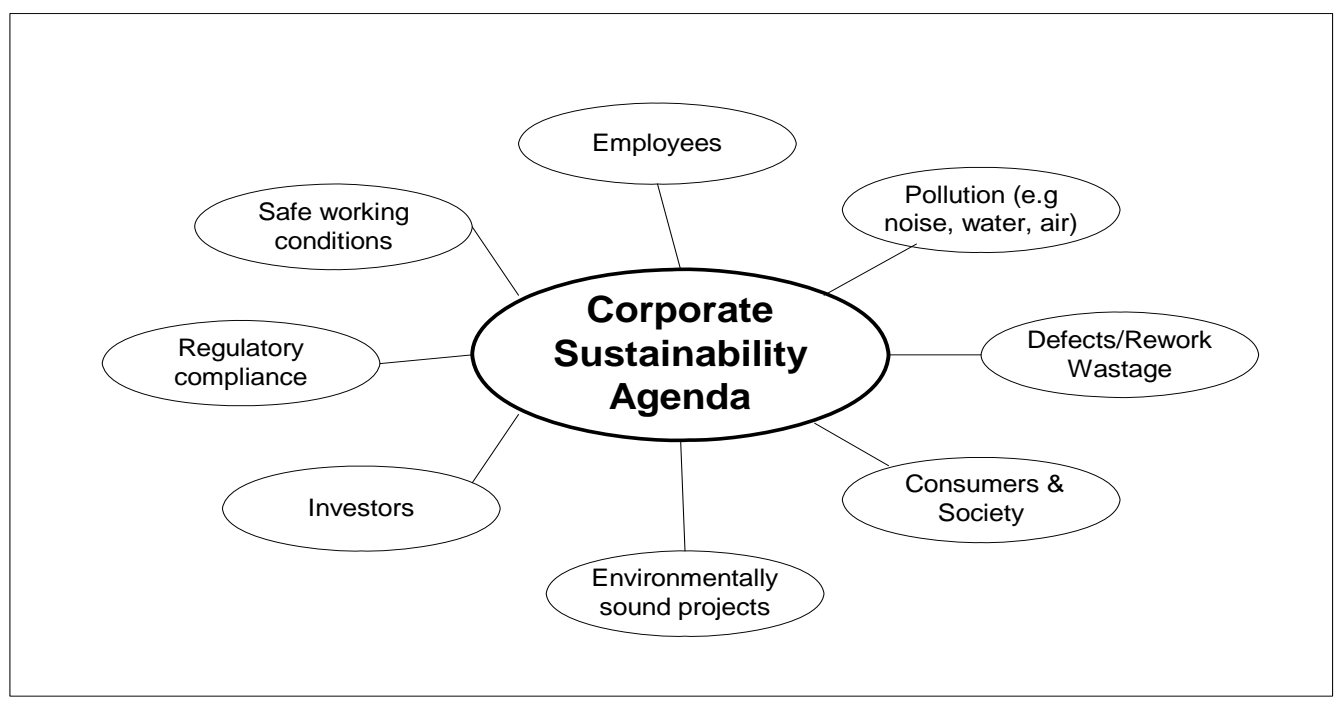

Figure 2: Skandia's Tree Metaphor

Source: Adapted from Edvinnson, 1997

\begin{tabular}{|c|c|c|c|}
\hline $\begin{array}{l}\text { Hard } \\
\text { Physical } \\
\text { Assets }\end{array}$ & Assets & $\begin{array}{c}\text { Debt } \\
\text { Equity }\end{array}$ & $\begin{array}{c}\text { Visible } \\
\text { component }\end{array}$ \\
\hline $\begin{array}{c}\text { Soft } \\
\text { Knowledge } \\
\text { Assets }\end{array}$ & $\begin{array}{c}\text { Goodwill } \\
\text { Technology } \\
\text { Competence }\end{array}$ & $\begin{array}{c}\text { Intellectual } \\
\text { Capital }\end{array}$ & $\begin{array}{c}\text { Invisible } \\
\text { component }\end{array}$ \\
\hline
\end{tabular}


Figure 3: Concept of KM maturity

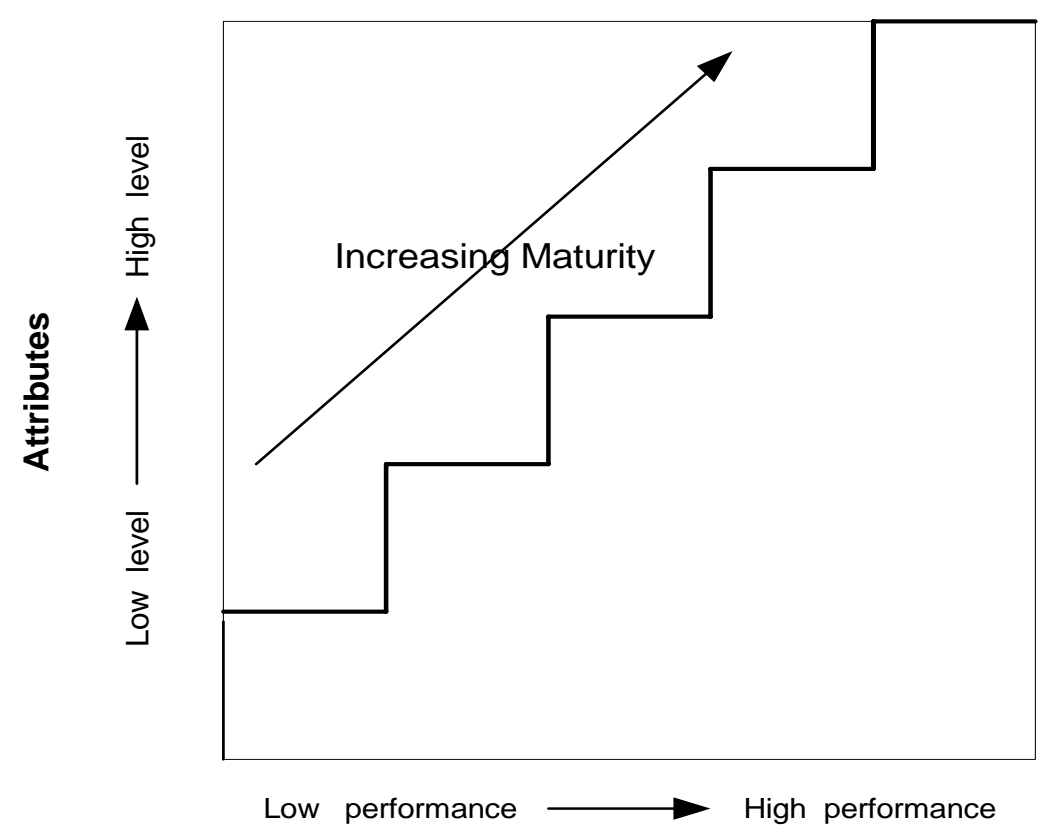

Attribute Dimension

Figure 4: The STEPS Maturity Roadmap

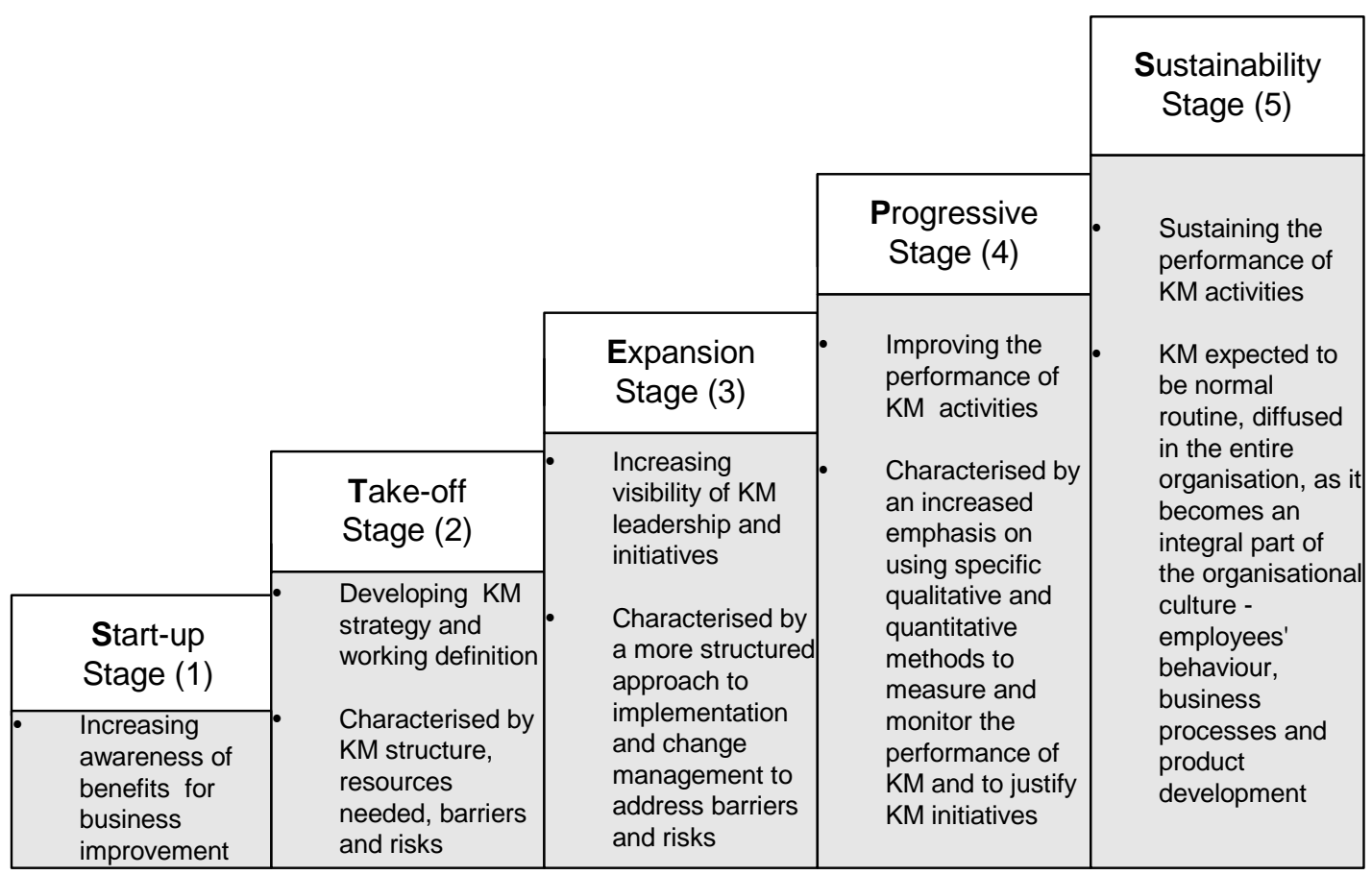


Figure 5: KM Maturity Levels of case study organisations

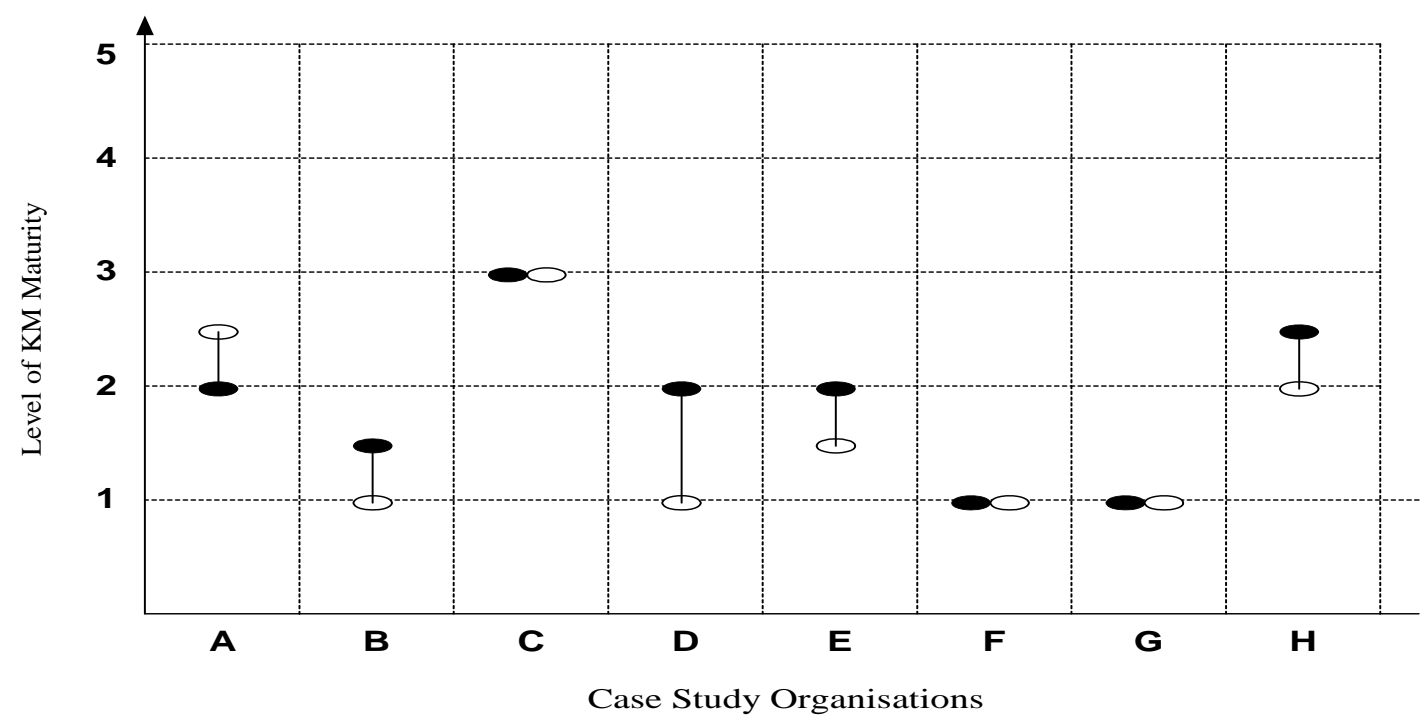

